\title{
The Political Economics of the New Silk Road
}

\section{Balázs Sárvári Anna Szeidovitz}

Corvinus University of Budapest

Fővám tér 8 ,

Budapest 1093, Hungary,

E-mail: balazs.sarvari@uni-corvinus.hu

E-mail: szeidovitz.anna@gmail.com

Abstract: What has now been coined the term XXI Century Silk Road had evolved from a speech given by Chinese premier Xi Jinping in Kazakhstan in 2013. It was initially a plan aimed at promoting the bilateral relations of China and its neighbors; however, the initiative had since then traversed the region's borders and become a global project.

This paper examines the Silk Road Economic Belt initiative in light of Chinese-EU relations. It reviews the initiation of the Silk Road Project and focuses on its political economic analysis through investigating the potential routes the Belt can take, the EU-Chinese trade and investment standings as well as the global political context that the increased cooperation and connection is likely to influence.

The paper uses the Modern Silk Road concept as an example of China's foreign policy in the wake of globalization and the emergence of a new multipolar world order. To set the stage we will begin with a political-economic approach of the New Silk Road. Highlighting the possibilities of Chinese high culture, which accommodate global governance, we state that the Modern Silk Road project is one of its materialized forms. The concept of the New Silk Road (together with the Eurasian Union) denies the previous era of corruption and personality cult and indicates a milestone in the development of China, proving that it is already a globally responsible power (Värk, 2015).

Even if transport by land is significantly more expensive than transportation by sea, the New Silk Road may have significant advantages: It may take only two weeks, saving potentially a week 
in shipping time, and diversify China's dependence on sea transport that could reduce the importance of its regional diplomatic conflicts. Already these aspects show that the purpose of the Modern Silk Road is basically not to explore cost-efficiency but to contribute to the establishment of a new, multipolar world order. The fact that the Modern Silk Road is a supply-driven concept in spite of the historical one underlines this argument. Even if politics dominate, henceforward directing the economic activities, we will nonetheless examine the China-Eastern European relations through the lenses of trade and investment as well.

After the initial analysis and description of the Silk Road Economic Belt as a tool of Chinese foreign policy, the paper goes on to examine the potential routes the railway takes from China to Europe. It reviews the trade and investment ties that the two entities share and assesses how this initiative contributes to the rise of Europe and China beside the USA. Lastly, it outlines how various regional and global powers are affected by the renewal of the Silk Road.

Keywords: China, globalization, global governance, One Belt, One Road, Silk Road, world order

\section{One Belt, One Road as One World, One Order}

The Silk Road project is a key element of a "new round of opening to the world" as the Chinese strategy, defined by Xi Jinping, reveals the goals and barriers of the country's global responsibility.

Our age is the transition period during which China is constantly further included in globalization. Although, due to China's intensifying presence, the global networks will have more and more Chinese characteristics, the concrete process is how China joins globalization and not how it modifies the current workflow, or how China spreads its own global narrative around the world. In other words, "China is seeking to 'supplement' the existing international order rather than to revise it" (Godement, 2015, p. 2). This restructuring does not mean the weakening of the USA, but a turn to global partnership, which empowers the developing countries.

It is essential to differentiate China's "One Belt, One Road" (yi dai yi lu, hereafter $O B O R$ ) initiative from any alliances since there are no direct political 
strings attached. On the one hand this refers to national, on the other to global geopolitical challenges. The rhythm of China's economy means a continuously increasing need for resources and markets, henceforward also a need for a progressive policy that ensures this broad meaning of national security. It already includes maintaining the infrastructure and the institutions needed for China's sustainable development (Geeraerts, 2011, p. 58).

Since "Foreign Minister Wang Yi said that 'economic imbalances' are the root causes of conflict and that China should provide more 'public goods' to mitigate them," (Godement, 2015, p. 7) there is a highlighted comparison with the Marshall Plan, which had quite similar rhetoric. In his speech at Harvard University on the 5th of June 1947, George C. Marshall (1947) stated that "Our policy is directed not against any country or doctrine but against hunger, poverty, desperation and chaos". Next to the above-mentioned similarity there are also basic differences between them. Whilst the American project's goal was to prevent the escalation of a new World War by consolidating poverty in Europe and to contain the Soviet Union, the Chinese target aims to build a strong partnership with the EU that fits the new global order, to pacify with market rules the (potential) conflict zones that will be crossed by the routes and to develop its poor western regions by linking them into the world economy.

In the European countries there was a big lack of investments and a need to alter their relations after the economic downturn of 2007. These intentions motivate them to intensify relations with China. Today's China's economic presence in the region is highly connected to the modern Silk Road concept that will be fully realized in about 35 years, as a recent report $(\mathrm{Li}, 2014)$ describes, what may exactly be the centenary of the foundation of the People's Republic of China (2049). The historical timing has special meaning since it is understood as one of the first steps of China's high-profile diplomacy (Huang, 2015). The ChinaEU relations are an essential milestone on the road China accepts to pursue within the global framework.

All these indicate a complete geopolitical plan. Its economic side is motivated by the disillusionment from the effectiveness of the Western institutions. Until the beginning of the economic crises, Western economies, and mainly the U.S., were accepted as the responsible powers for the balance of the global economy. The downturn served as a wake-up call for China to take its part in rebalancing these imbalances through, for example, the $O B O R$. China decided to accept the law of globalization and to fulfill the given void. China in that way adapts to the change in global governance that turns the $O B O R$ concept into a contribution to the stability of the new world order. 
It is necessary to build up a supply-based commercial system that differs from the historical Silk Road. That was an organically developed infrastructure to meet foreign demand for Chinese silk. The idea of the OBOR comes from China, more concretely from its understanding of the distribution of global power in the 21 st century. This time, unlike in ancient or medieval times when cultural exchange was subsidiary, the production process will follow geopolitical planning and thus a global vision. Nowadays, this normative convergence is the primary goal and in itself the political side of the $O B O R$.

It is a much deeper strategy than a simple cost-benefit analysis. This already shows that China did not simply import the laws of classic capitalism. Its cultural heritage is the source of this development and the so-called $O B O R$ project is a pragmatic tool in that regard. This proves that the common global interests are the sources of competitiveness.

Henceforward, it is a misunderstanding to explain this or any other Chinese project as a regime-changing tool, like Zhang Jun expressed:

Clearly, China has faced major challenges within the existing global system as it tries to carve out a role befitting its economic might. That may explain why, with its "one belt, one road" initiative and its establishment of the Asian Infrastructure Investment Bank (AIIB), China's government is increasingly attempting to recast the world order - in particular, the monetary and trading systems —on its own terms. (Zhang, 2015)

The Sino-European partnership has vast strategic potential. China is increasingly suspected to be a Trojan horse in the European Union since its growing activity may target to weaken the continent's political economic power. However, that is far from Chinese interests. The complexity of the phenomenon needs to state that (1) China is not a leading power in Europe; (2) it does not have the capacities to serve as a dividing force. Essentially, the suspicious rhetoric does not harmonize with the Chinese foreign policy guidelines that provoke strong and united Europe since only this can maintain the international environment for the sustainable development of the Chinese economy and society. From a European point of view, the normative convergence of a global vision at a European level is difficult, not to mention the strain of merging it with the Chinese vision. It is false to think of Europe as a single entity. In reality, various national interests are competing against each other and many cultural restraints hinder the creation of a single common European standpoint. 
China currently has interests in a multipolar world instead of an America dominated unipolar one that highlights the role of a prosperous and strong EU since "it is the most likely candidate to become another pole" (Turcsányi, 2014). As Geeraerts (2011, p. 57) expresses, "[t] he unipolar moment is definitely fading and slowly giving way to an international system characterized by multilayered and culturally diversified polarity".

To further the proposal, the Chinese government has set up two institutions, the Asian Infrastructure and Investment Bank (AIIB) and the Silk Road Fund. The AIIB has been set up with 50 members including countries outside of Asia. Like many of the other aspects of the $O B O R$, the AIIB is to become fully operational in the future, intended for use by the end of 2015. Its authorized capital is 100 billion U.S. dollars (in comparison, the shareholders of the World Bank own over 250 billion U.S. dollars) (The World Bank, 2015). The Silk Road Fund Co Ltd. is a 40 billion U.S. dollar fund dedicated exclusively to developing the transport and trade links in countries and regions along the Silk Road (Fung Business Intelligence Centre, 2015, p. 8). Other regional funds have also been set up (e.g., China-ASEAN Investment Cooperation Fund (for South-East Asia) and the China-CEE Investment Cooperation Fund (for Central and Eastern Europe)), which assist China's large international infrastructure construction policies (van der Putten \& Meijnders, 2015, p. 31). The latter is endowed with 3 billion U.S. dollars and was announced in December 2014 with the aim to further enhance cooperation including plans of constructing "a new corridor of interconnectivity" (Rolland, 2015, p. 2).

Even if these concepts seem to be well founded, we should admit both sides of China's benefits due to its presence in the region: the short term goal of economic self-enrichment and the long-term (geo)political goals. Only the future will show how China will go on to use its influence to push its interests.

\section{The Silk Road Economic Belt proposals}

Mr. Xi Jinping delivered a speech at Nazarbayev University in Kazakhstan entitled 'Promote People-to-People Friendship and Create a Better Future', which outlined China's foreign policy towards its (foremost) immediate neighbors (Ministry of Foreign Affairs of the People's Republic of China, 2013). He revealed a regional cooperation with the Central Asian nations revolving around a pentagram of collective issues: communication, connectivity, trade facilitation, enhancement of monetary circulation, and strengthened people-to- 
people exchanges. In essence, the complementary five elements create a tighter economic bond between the region's economies to the extent where China cannot become an estranged member. Two methods to achieve the above were disclosed: the Silk Road Economic Belt and the Maritime Silk Road.

The Belt and the Road together would "create an economic cooperation area that stretches from the Western Pacific to the Baltic Sea" (Fung Business Intelligence Centre, 2015, p. 3). The Belt railroad has various proposed routes (outlined in the following section) but in general it is directed from the Chinese coast towards the west, through China's Xinjiang province, through the Central Asian countries into Eastern Europe, its destination - the Baltic Sea. The Maritime Silk Road is a sea-trade route to Europe, which complements the Belt, but incorporates China's Southeast Asian neighbors and the Indian Ocean's coastal states. The two together would not only tie China unconditionally into the trade circuit of Europe and Asia but also promote it to be a country that acts unambiguously upon its global responsibility.

Prior to divulging in the details of the Silk Road Economic Belt, the following elements of the current state of affairs must be highlighted. First, this proposal was initially intended to reinforce relationships between China and its neighbors; thus, the global initiative that has evolved from this plan is subordinate to it. Second, the proposal in its current form is not definite, "rather it is an umbrella concept under which many inter-related projects will be converging" (Vangeli, 2015, p. 21). Explicitly speaking, there is no blueprint of the intended trade routes and hubs, nor is there a comprehensive collection of international agreements backing the initiative. At the point of writing, what we do have is a fluid concept encompassing many countries and multiple potential routes converging under the label of the OBOR. Third, and stemming from the above, the proposal is not solely economic and trade-related - in essence, in the future hopefully this initiative will enclose other social, cultural, and security areas as well. Lastly, at this point in time, the first stage of the Chinese proposal focuses on building an infrastructure network that will later flourish to become the ferry of ideas and goods. For this reason Chinese investment and infrastructure development is currently the priority. 


\section{Infrastructural perspectives}

Trade through railroads between East Asia and Europe only accounts for 3 to 3.5 per cent of the total trade between the continents. This is a trifling percentage when viewed in comparison to the 95-96 per cent of the trade conducted by sea (Erdősi, 2015, p. 109). Furthermore, transport by land is significantly more expensive than transportation by sea. This is primarily due to the long delays at the borders caused by bureaucracy, tariffs and logistical ineptitude. Yet what brings so much potential to the Silk Road Economic Belt is the shorter journey that could be achieved if the high-speed railways are constructed (van der Putten \& Meijnders, 2015, p. 28). While maritime transportation takes roughly 2.5-3 weeks, by land the duration is only 13-15 days. This, coupled with China's need to diversify its overdependence on sea transportation in foreign trade, indicate the initiative's importance (Liu, 2014, p. 3). When analyzing the pros and cons of various forms of transport, in the end, transportation by land is more expensive; thus, currently this route is reserved for more expensive and valuable commodities, which are immune to colder weathers, but are sensitive to sea travel. Regardless of the expenses, in terms of China's aims, the purpose of rejuvenating the Silk Road through the $O B O R$ is not first and foremost intended to be cost-efficient. Rather, it proposes to incorporate China's western region into the global economy, thereby geopolitically partaking in the establishment of a multipolar world order.

There are currently two main routes connecting Asia to Europe: the TransSiberian Railroad and the Second/New Eurasian Continental Bridge. The TransSiberian Railroad runs almost exclusively through Russia between Vladivostok and Rotterdam and is not considered part of the Chinese proposal. The New Eurasian Continental Bridge runs from Lianyungang to Rotterdam and is the main target of the Silk Road Economic Belt Initiative. Some also raise the possibility of a Third (Southern) Eurasian Land Bridge, but this is merely hypothetical, as due to the brutal physical difficulties and high costs incurred in its establishment, it can be considered as a dysfunctional illusion, especially since the maritime route is nearby (Erdősi, 2015). According to Chinese viewpoint, the Eurasian Continental Bridge is the main route connecting East to West, which is to be supplemented by several smaller north-south corridors along the route to connect more areas into the initiative and international trade (van der Putten \& Meijnders, 2015, p. 25).

Currently, there are various routes in use connecting China to Europe: the YuXinOu railway between Chongqing, China through Duisburg, Germany, to 
Antwerp, Belgium; the fastest (12-day journey) route: Rongou railway between Chengdu and Lódź, Poland; the Zhengzhou railway between Hamburg and Zhengzhou; the HanXinOu railway connecting Wuhan, Hubei Province with Lódź, Poland; and, the YuXinOu railway, which starts at Yiwu, Zhejiang Province and ends in Madrid, Spain. "All of these railways are designed for cargo trains transporting goods between China and Europe, and are said to effectively help save cost and time" (Men, 2015, p. 13).

Figure 1. Railway and road corridors connecting the Central Asia regional economic cooperation member countries

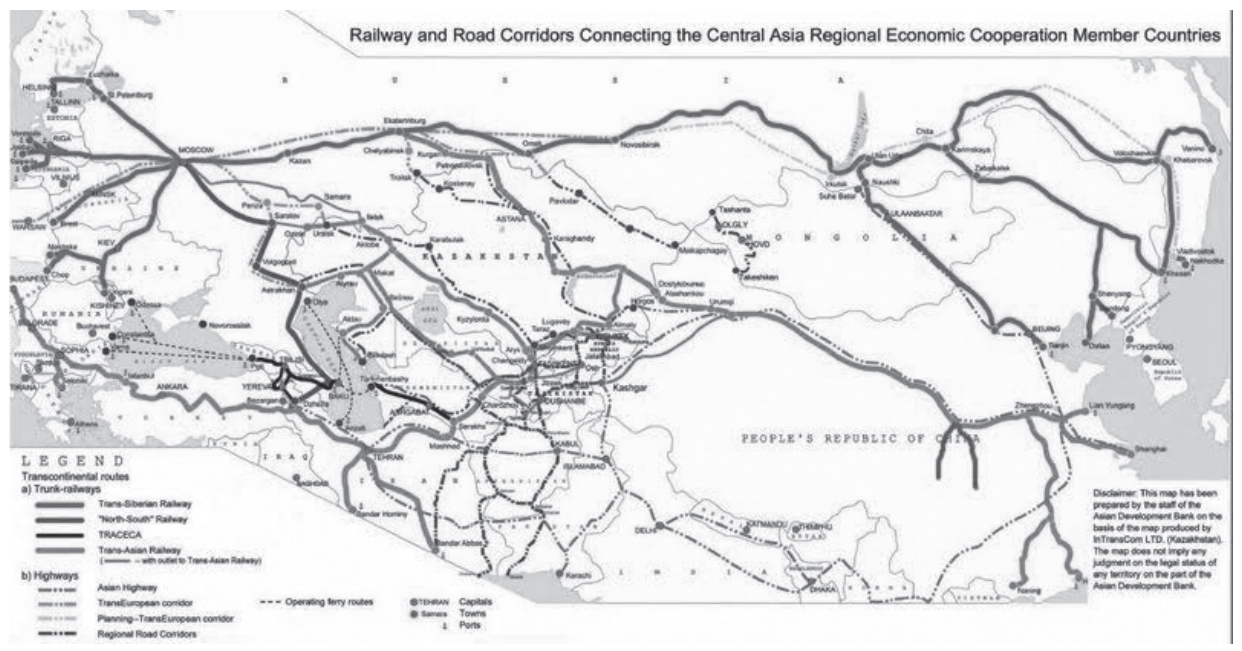

Source: Railway Road Connections Map, 2005, edited by the author.

The Chinese aim is, on the other hand, to build a single, uniform railroad, perhaps towards Iran or Turkey, which would be completely independent (Erdősi, 2015, p. 120). The main aim of the Chinese efforts to develop the New Eurasian Continental Bridge is to bypass Russia and counter the monopoly it has on trade (Erdösi, 2015, p. 116). The proposal, also known as the TRACECA Silk Wind block train route, will aim to connect Central Asia with Turkey through Azerbaijan and Georgia, which-according to the plans - would significantly decrease the cost and time of transportation between China and Europe. It "aims to construct new high-speed multimodal container transit routes with advanced technologies such as electronic information exchange, simplification of border crossing procedures and reduction of transportation time" (Fedorenko, 2013, p. 17). 
The Silk Wind would cross Kazakhstan, use a ferry across the Caspian Sea between Aktau and Baku and diverge towards the Black Sea and cross northern Turkey through Istanbul into Europe. This would amount to an estimated 11 to 12day journey and cost about half the Chongqing-Duisburg journey (TRACECA, 2012). However, this route's development depends on various hurdles: switching between gauges at border crossings, a ferry across the Caspian Sea, the KarsEdirne railway traversing Turkey, and the rail tunnel under the Bosporus. In terms of China's geopolitical strategy in the region, hurdles are peripheral.

Chinese interests in joining the new world order include the growth of developing neighboring regions and second the plight involved in its venture. The long-term goal for China is the construction of a new high-speed railway from China to the United Kingdom through Kazakhstan, Uzbekistan, Turkmenistan, Iran, Turkey, Bulgaria, Romania, Hungary, Austria, Germany, Belgium and France. The project is estimated to cost around 150 billion U.S. dollars and is planned to be finished between 2020 and 2025 (van der Putten \& Meijnders, 2015, p. 27).

Nonetheless, at this point in time, the Chinese efforts' pathway remains ambivalent; the Eastern half of the route is roughly fixed; however, the Western half-especially the entry to the European Union-remains undecided. There are two possible routes that the initiative can take: (a) China-Central AsiaRussia-Europe pathway, or towards the south of Europe, (b) China-Central Asia-West Asia/Persian Gulf-Mediterranean path.

The European railway infrastructure is relatively well endowed; yet large projects of infrastructure development are needed in the Central and Eastern European countries, as they "lack unified standards" and the technical elements of the railways (double track rate and the electrification of the railway lines) are not in sync with the Chinese, which impedes the uninterrupted transport, storage and handling of goods (Liu, 2014, p. 11). The establishment of good Sino-European relations is an element of the new multipolar world order currently under construction in China's regional geopolitical strategy. By this reasoning, cooperation in multiple elements outlined by Xi Jinping and the establishment of uniformity in the two individuals' relations are symbolized by the building of the $O B O R$. The flow of ideas and goods, which promotes "people-to-people friendship and creates a better future" begins with the creation of unimpeded traffic - symbolized by the construction of a single, uniform, synchronized railway line. These developments could serve as a possibility for Chinese investments in the region, which in some instances have already begun. 
China's infrastructure development policy has long incorporated the element of connecting ports and railways (van der Putten \& Meijnders, 2015, p. 28). As the Maritime Silk Road and the Economic Belt are complementary, there are efforts to connect the two in the Greek Piraeus hub (van der Putten \& Meijnders, 2015 , p. 14). The Chinese investment of the Greek port started in 2009, when the Chinese state-owned enterprise China Ocean Shipping Company (COSCO) obtained a 35-year concession to operate piers II and III of the port. ${ }^{1}$ The large investments resulted in a five-fold increase in container throughput and substantially higher efficiency (van der Putten \& Meijnders, 2015, pp. 10-11). This, coupled with the improved transit capacity of the port and its connection to the national railway lines, has resulted in the port's development into a major hub of the eastern Mediterranean, it functions as the "world's fastest growing container port" and became pivotal to China's Eastern Mediterranean policy (Vangeli, 2015, p. 24). To further this development, the Chinese government has announced the intended construction of a high-speed railway from Piraeus to Budapest $^{2}$ via Skopje and Belgrade (van der Putten \& Meijnders, 2015, p. 28). Another line is also being proposed, which would connect the port of Constanta at the Black Sea to Vienna through Bucharest and Budapest (van der Putten \& Meijnders 2015, p. 28). The development of Sino-European relations through the construction of railway lines in South-Eastern Europe is an example of China's geopolitical strategy in the region. The partnership it tries to establish fits the new global political order, which converges on common global interests.

The first phase of the $O B O R$ is the establishment of the infrastructure necessary for development, including rail, highway, aviation and maritime (Liu, 2014, p. 6). Under the $O B O R$ initiative, these construction projects are primarily financed, constructed, supplied, or operated by Chinese state-owned firms, or firms close to the Chinese government (van der Putten \& Meijnders, 2015, p. 8). Southern Europe boosts especially amiable ties with China. Countries such as Greece, Portugal, Cyprus and Malta give home to large and mid-scale Chinese investments (Vangeli, 2015, p. 24). Once finished, these firms would have a high degree of influence over the transportation network. From a Chinese perspective, this would maintain the stability of the flow of trade, or further enable the government to allow alternative routes by which trade could take place. What would essentially manifest is a strong Chinese influence and others' dependence on these trade routes (van der Putten \& Meijnders, 2015, p. 32).

Pier I remained in the ownership of the Greek state-owned Piraeus Port Authority.

2 The Chinese, the Hungarian and the Serbian Prime Ministers decided in November 2013 to reconstruct the Budapest-Belgrade railways from Chinese capital. Two years later in September, the Hungarian Prime Minister Viktor Orbán empowered his ministers to finalize the construction plan with the People's Republic of China. 
Most of the goods traded between the EU and China are manufactured goods. Currently the YuXinOu railway connects Asia's largest laptop production base in Chongqing with Europe. The main good it transports to Europe is IT products. What is common between all railway lines is the lack of return trips from Europe to China. There are numerous reasons for this discrepancy. Namely, the Chinese destinations are not distribution hubs; in comparison to maritime trade, which localizes around ports that are simultaneously distribution hubs, it costs too much to transport the imported goods to other cities via international railways (Maxxelli Consulting, 2015). Furthermore, due to its infancy, the publicity is not wide enough and many Chinese firms do not want to relinquish the already in use alternatives. What many fathom is that unless the value of the Chinese exports increases, the proposed railroad investments would be deficient (Erdösi, 2015, p. 120).

What spikes up the cost of transportation by railway are the lack of goods on the return journeys from Europe and the inefficient modes of transport of various goods. Furthermore, government subsidies of various Chinese provinces' hubs have led to distorted prices and unbalanced competition in the market (Liu, 2014, p. 8). The current state of affairs is worth the Chinese foreign policy's geopolitical strategy since connecting into the new world order and endowing it with not just Western, but Chinese characteristics dominates the short-run cost-efficiency.

\section{China-Eastern European relations: trade, investment and politics}

EU-Chinese relations had been established in 1975 and since then the two partners have developed their cooperation in various fields. The EU is especially important to China as it is its largest trade partner, and hosts the maritime corridor to the U.S.A. (van der Putten \& Meijnders, 2015, p. 29). Within this framework, Central and Eastern Europe has the theoretical possibility to enjoy amicable relations with China that is not plagued by historical conflicts or outstanding issues (Liu, 2014, p. 2).

The importance of Central and Eastern Europe for China lies in its possibility to become a three-fold gateway to Europe: geographically, cooperatively, and brand-wise (Liu, 2014, p. 7). Essentially the physical placement of Central Europe makes it unavoidable in the pathway of the Economic Belt. Furthermore, its mentality and capabilities bridge the two potential partners, making it easier for Chinese companies to enter the EU's market. This, however, must not be 
mistaken with overall Chinese dependence on the EU; the Chinese government at present has "an increased ability to influence which routes the trade between China and the EU flows", and simultaneously develop routes which bypass Europe towards Africa and the Middle East (van der Putten \& Meijnders, 2015, p. 6).

The Chinese OBOR program, in essence, provides a structure for Chinese diplomatic, commercial, and foreign infrastructure policies around the world to expand Chinese exports and access to raw materials, and obtain new markets for Chinese trade and investment (van der Putten \& Meijnders, 2015, p. 29). China can, in effect, concurrently contribute to Eastern Europe's rise and in that way to a new, more balanced Europe.

\subsection{Trade}

Trade between the EU and China is on the rise and had exceeded 615 billion U.S. dollars in 2014, an increase of 9.9 per cent to the previous year (Yang, 2015 , p. 6). At present the trade balance of the EU-10 towards China remains significantly negative; there is a three-fold difference between its imports from and its exports to China, a proportion that is slightly improved by the fact that much of the imports contribute to higher value added re-exports towards Western Europe (Matura, 2012, p. 108). In comparison, Germany acquires 47 per cent of the EU exports to China, a ratio in which its Eastern European counterparts remain strikingly at a disadvantage; the EU-10's trade share to China was only slightly more than 3.5 per cent (Matura, 2012, p. 108). There is great potential for Eastern European trade with China; however, much of it is hindered by the inability of Eastern European enterprises to meet Chinese quantity demands.

The Ukraine and Belarus - two countries whose geographical position bridges the Silk Road Economic Belt with Russia and Central Asia - have the potential to offer China agricultural produce, military and advanced technology in return for investments (Vangeli, 2015, p. 24). China has already invested several billion U.S. dollars in multiple Ukrainian projects of which an industrial and technology park is of salient importance (Vangeli, 2015, p. 24). The Western Balkans is another area of great potential for Chinese investments. The countries are not yet members of the EU; therefore they are "more flexible" and relatively poor to be eligible for Chinese developmental aid (Vangeli, 2015, p. 23). Or perhaps due to their lack of EU membership, they might be considered as a disadvantageous investment in the eyes of Chinese investors (Matura, 2012, p. 107). 


\subsection{Investment}

In terms of investments, the Chinese have recently become net capital exporters in 2014; the Chinese outward direct investment (ODI) overtook the inward foreign direct investment (KPMG, 2015, p. 10).

The pre-financial crisis era China policies of the European countries can be categorized into four groups: Ideological Free-Traders, Assertive Industrialists, Accommodating Mercantilists, and European Followers (Matura, 2012, p. 106). The first group stressed the importance of politics, without diminishing trade relations, whilst the Assertive Industrialists were willing to confront in both political and economic issues. The third group aimed to foremost create good economic relations with China in the hope of that spilling over to other areas of cooperation. Finally, the last group deferred their relations with China to the EU. However, the crisis significantly liberalized the state of minds of the region's leaders and their policies became increasingly more economically liberal towards China (Matura, 2012, p. 106). As the region's traditional partners (the U.S. and Western Europe) had rescinded, the region was in desperate need of FDI (Vangeli, 2015, p. 23). This is visible in the recent statistics between the entities, as "Chinese investment in the EU reached USD 9.41 billion in the first 11 months of 2014, a nearly three-fold increase" (Yang, 2015, p. 6).

The recent trends in Chinese ODI indicate that as the Chinese economy develops and becomes more innovative, their destination is also beginning to be subject to change from resource-rich developing countries to developed countries. At present the top ten countries receiving Chinese ODI are: U.S., Peru, UK, Australia, France, Italy, Singapore, Portugal, Canada, and the Netherlands (KPMG, 2015, p. 12). This trend is especially convenient for Europe and to some extent Central and Eastern Europe as well.

On the other hand, whilst Chinese FDI to the EU is a real phenomenon, the share of it remains insignificant. In 2010, Chinese investments in the EU exceeded 12 billion U.S. dollars, the total level of FDI to the EU in that year was 6,890 billion U.S. dollars, and Chinese investments equaled less than 1 per cent (Matura, 2012, p. 106). In the EU-10, Chinese investments only amounted to 828 million U.S. dollars, which equaled 0.12 per cent of the total FDI in that region (Matura, 2012, p. 106). As Central and Eastern European states' transitions ensued from their accession to the EU, most of the Chinese capital flows tend to seep to the sub-region of the Commonwealth of Independent States (Matura, 2012, p. 107). What potential remains in Central and Eastern Europe is its advantageous geographic location and infrastructure 
that have the possibility to provide the Chinese investors who plan to export to the EU with some value (Matura, 2012, p. 108).

The above phenomenon is only slightly outbalanced by the Bilateral Investment Agreement with the EU that the Chinese had chosen to replace the plethora of investment treaties with (Stahl, 2015, p. 18). This new and ambitious initiative is currently under negotiation and would serve as a two-way investment opportunity that would greatly serve China's economy and in the event of slower Chinese economic growth would help bring stability (Schweisgut, 2015, p. 9).

\subsection{Politics}

China and the EU are celebrating their relations' 40th anniversary this year. Overall, the two entities have had both positive and negative elements in their relationship, including the Iranian nuclear issue, climate change, or international trade negotiations (Yang, 2015, p. 6). The main constituent of the countries' relationship is outlined in the China-EU 2020 Strategic Agenda for Cooperation (EEAS, 2013). The Agenda was agreed upon in 2013 and serves as the basis and the main document of the future EU-China Summit (Schweisgut, 2015, p. 8). It comprises of four pillars: peace and security, prosperity, sustainable development, and people-to-people exchanges. These include various areas of cooperation such as trade and investment, agriculture, industry and information, transport and infrastructure, urbanization, etc. (for more information see EEAS, 2013).

The Chinese and European leaders share common interests related to foreign policy, namely "the necessity to invest in infrastructures in regions that still need to create the enabling framework to raise their income and access international markets" (Schweisgut, 2015, p. 9). Within this context, the EU welcomes the Chinese $O B O R$ initiative, although it places inherently large emphasis on reinforcing competitiveness and a requisite of transparent bidding processes (Schweisgut, 2015, p. 9). This, however, can also become a source of political friction, as European companies will receive heightened foreign competition and the possibility that Chinese SOEs will be unable to comply with EU norms (Vangeli, 2015, p. 26).

Regarding the Silk Road, cooperation between China and Europe has the possibility to run on three platforms: Central and Eastern European countries, the EU, and the Asia-Europe Meeting (ASEM). The cooperative mechanism between China and the CEE countries is the primary mode of communication between China and the EU (Liu, 2014, p. 4). This is foremost due to the Eastern 
European countries' foreign policies of "opening to the East". However, there is a lack of common EU policy towards China between the Member States.

Bilateral relations, such as the ' $1+16 /$ CEE $16+1$ summits', have the possibility of fracturing unanimous EU positions. These summits between the heads of government of 16 Eastern European countries and China have quasiinstitutionalized the cooperation and are relatively important within China's Foreign Affairs Ministry (Stahl, 2015, p. 18). Chinese scholars believe that the CEE16+1 would be "crucial" to enhancing the connectivity between Asia and Europe; thereby, it would facilitate the Silk Road (Vangeli, 2015, p. 23). Yet, Central and Eastern European countries are in competition for Chinese investments (Matura, 2012, p. 105). Furthermore, since the region itself does not have a cooperative China policy, the Chinese have the ability to cherry-pick the best offers (Matura, 2012, p. 105).

\section{Global political context}

\subsection{Chinese interests}

China has numerous interests in promoting the Silk Road Economic Belt. Most importantly, it serves as development of the western regions; China sees the Silk Road and the establishment of transportation infrastructure as the answer to developing its western region and the neighboring Central Asian nations. In the future trade liberalization and monetary cooperation will serve as the basis of a new regional economic community with new regional hubs and large industrial parks (Rolland, 2015, p. 1). The basis of the initiative is that transcontinental connectivity could "boost trade, stimulate technological development and transform the strategic landscape" (Rolland, 2015, p. 2). At present, the western autonomous Uyghur region of the country is lagging in growth in comparison to the shore. Throughout the history, this area had not enjoyed positive relations with the Chinese leadership, spurring social tensions that amounted to security threats. The government is trying to resolve these issues through embracing the region in the Chinese economy. The market on the other hand is still irresponsive to developing that region; there is a large discrepancy between the amount of FDI the East and the West receive. Whilst Central China is becoming a more popular investment destination (a 7.5 per cent registered FDI growth in 2014), the western provinces are behind with a registered 1.6 per cent growth in 2014 (KPMG, 2015, p. 27).

Another reason as to why this initiative is important to China is the questionable future of the Chinese economy. The main concerns are 
economic growth and to what extent could domestic consumption be a pillar of that - as it is shown by the data as well, in the last three years China's trade objectives were not achieved. However, it is quite popular to state that China is giving up its export-oriented model-although this is far from reality. The current trend in the Chinese economy is that following the global economic crises and the emergence of its middle class, the government urged the shift to a consumption-led economy but this does not mean that China is giving up its targets in export.

From 1979 onwards, China — as a developing country — chose export-oriented development as a sustainable development model. In comparison, many other developing countries focused on increasing their domestic demand. The Chinese model proved to be successful, yet with the financial crisis coupled with pressure from abroad by the EU and the USA along with Chinese priorities, starting from 2006 China decided to focus its growth on increasing domestic demand.

However, the shift from an export-oriented growth model to one relying on domestic demand is not instantaneous. Currently, the Chinese economy still has abundant resources (in terms of an educated labor force, infrastructure and SMEs) as well as a strong household propensity to save, which foreshadow a dual growth path of both increasing domestic demand and exports. Not only does switching to domestic demand rely heavily on households to reduce savings and focus on consumption, but it collides with the goals of Chinese SMEs that were able to enter the international market. The Chinese strategy of the 21 st century is to establish a strong institutional background and quick decision-making to go hand-in-hand with the sustainment and development of the export-oriented model. As Inotai argues, China will shift its economic policy from a simply export-driven one (that China had chosen as a single country among the big developing states) to a more balanced structure (Inotai, 2011). The Chinese export will not decrease as the government motivates consumption to increase gradually, hand-in-hand with imports.

The growth of the tertiary sector has become the driver of the economy, accounting for 48.2 per cent of China's economic output in 2014, while at the same time the manufacturing sector displayed a negative trend (KPMG, 2015, p. 26). "China's economic restructuring [which focuses on the following segments of the economy: infrastructure investment, SMEs, real estate, service sector, agriculture, financing cost, exports] is creating more development potential for private capital, especially small and medium enterprises" (KPMG, 2015, p. 5). 
Further positive element for China is the possibility of securing energy resources from its western neighbors, which could minimize the state's reliance on the Strait of Malacca (Rolland, 2015, p. 2). Whilst the OBOR policy indicates that China does not solely view Central Asia as the provider of energy resources, China is gladly willing to provide generous loans to Central Asian countries to develop their gas fields. It has already provided 4 billion U.S. dollars to Turkmenistan and 5 billion U.S. dollars to Kazakhstan (Fedorenko, 2013, p. 13). As repayment for the financial aid provided by Beijing to its neighbors and the development of their transport and communications infrastructures through contracts and subsidies for China's national rail car manufacturer, the country will strengthen its position in foreign competition and advance in the overseas markets (Rolland, 2015, p. 2). Although, as previously discussed, within the EU transparent bidding processes are a prerequisite, meaning that at best it would increase Chinese companies' competitiveness in that region (Schweisgut, 2015, p. 9).

However, following a micro- and macroeconomic approach there are significant critics of Chinese planning. Many scholars (e.g., Anbound, Xu Gao) point out that the new concept of the three commercial directions (east, west and south) is beyond the Chinese capacity. As they warn, the western route is logical but further diversification disperses the Chinese resources; meanwhile China does not have an advantage in competitiveness compared to ASEAN countries. As Xu (2014) argues, this project is a "micro-hazard" since it takes huge investments in infrastructure, which already represents a quarter of China's total investments and offers low returns and thus a potential debt-crisis.

\subsection{Central Asian interests}

Central Asian economies are beginning to rely heavily on China. From a Chinese standpoint the base of their relationship is to secure and diversify its supply of energy. In this regard, the "proximity and abundant resources of Central Asia makes the region a perfect business partner" (Fedorenko, 2013, p. 14). As a form of repayment, China provides investments. For Kazakhstan, entry to the world market is possible via China, which has become the country's primary recipient of its minerals and other raw materials (Erdősi, 2015, p. 122). China's dominance in the region has become apparent. The "infrastructure for oil" barter exchange has led many Chinese companies to battle with the high altitudes and build railroads; paying for oil and other raw materials with preferential loans (Erdösi, 2015, p. 119). China is also planning to convert the Kyrgyz railway from Russian track gauge sizes to the international standard (Fedorenko, 2013, p. 14). 
On the one hand, the Central Asian states are delighted by the Chinese investments, on the other hand, they do not want to rely exclusively on China (Fedorenko, 2013, p. 14). In this regard, the Silk Road project, if it will run towards Iran and Turkey, would help secure a market for the Central Asian states' grain produce (Erdösi, 2015, p. 122). This is just one example of the possibilities that the Silk Road Economic Belt could bring for the region, which at present remains somewhat limitedly linked to international trade.

\subsection{Russia's interests}

Russia's main interest in the Silk Road project is to continue securing its interests - a legacy of the Soviet Union - in Central Asia. To that end, following the collapse of the U.S.S.R., that region had received ample aid from Russia, who means to prolong those investments, which tied the states to it (Fedorenko, 2013, p. 15).

Due to the inherently different trade practices of Russia and China, the Second Eurasian Continental Bridge has little direct impact on Russian interests. Russia relies on the Trans-Siberian railroad to transport raw materials to the East to satisfy China's demand. This relationship is unlikely to be teetered (Erdösi, 2015, p. 121). Instead, what Russia focuses on is the Eurasian Union. Through this initiative it aims to continue holding the Central Asian states within its sphere of influence (Fedorenko, 2013, p. 16).

\subsection{U.S. interests}

The U.S. also has a New Silk Road strategy in the region, which was revealed in 2011. Its primary focus is Afghanistan and its neighbors' political stability. What Afghanistan needs is integration into the world economy, which is to be done along much of the same lines of foreign policy as China does in Central Asia: by building infrastructure that would enable that (Fedorenko, 2013, p. 5). This includes the TAPI (Turkmenistan-Afghanistan-Pakistan-India) gas pipeline, or hydropower from Kyrgyzstan and Tajikistan to Pakistan and Afghanistan (Fedorenko, 2013, p. 6). 


\subsection{European interests}

Uniquely, Europe's aim in the cooperation with rising China is to achieve its normative convergence. It would like to mobilize the private sector for infrastructure investment and promote regional cooperation (Schweisgut, 2015, p. 10). For that purpose Europe is prepared to invest in the development of China-but, in turn, it expects China to meet European standards. This is the European scheme to maintain global peace and to fully qualify itself as a first tier leading global actor.

Europe sees itself as the model China should aspire to. EU policy is based on the belief that 'human rights tend to be better understood and better protected in societies open to the free flow of trade, investment, people, and ideas. (Geereaerts, 2011, p. 63)

With China it aims to build international collaboration to promote peace, prosperity and sustainable development within Eastern Europe and Central Asia (Schweisgut, 2015, p. 10). Its main purpose is diversification and the potential to gain investment (especially for Central and Eastern Europe). In that regard, the CEE countries would like to become the gateway to the EU for Chinese investors. Henceforward, the $O B O R$ vision provokes dynamic competition in the $\mathrm{CEE}$ region since all the countries are intent on becoming the bridge between China and EU through this commercial project. (Hungary was the first European country to officially join China's New Silk Road project.)

The New Silk Road policy of China has the possibility of providing a great opportunity for Europe, especially if the EU and China can harmonize their policies and "explore common initiatives" (Vangeli, 2015, p. 25). At the same time, its complexity means that the EU's relations with its neighbors will include a foreign player. Not to mention that the distance between Europe and Asia will significantly decrease and receive numerous other players that enhances the new global order, the so-called global partnership.

China is obviously ready to learn from Europe as it extracts common interests, but finds it culturally impossible to respect it as a political model since the power of Chinese unity has such a historical precedent that Europe can hardly aspire to ever achieve. What remains a challenge is that in the event that a fractured Europe remains without a single common China policy, the possibility of Chinese ventures contributing to a two-track Europe will be threatening (Vangeli, 2015, p. 25). 


\section{Conclusion}

As is perceivable from the above, the Silk Road Economic Belt initiative has overshadowed a purely trade route - as the historical one did also since it meant a corridor along which at least seven religions and several influential Western thinkers arrived to China. Although its concept remains the same as that of the historical Silk Road its means to consciously develop regions along the route are primary to trade. China's interest is to participate in the establishment of the international environment, as opposed to being adherent to the rules set up by other nations. Consequently, the current trends of globalization will hold not just Western, but Chinese characteristics as well. Developing its neighboring regions, and building the Silk Road Economic Belt, symbolize the strategy China follows in establishing itself and Europe in the multipolar world. Historically, cities along trade routes flourished and China's incentive is to flourish and develop its western regions and neighbors.

Europe is China's major trade partner. In that regard, it is impossible to exclude it from any of the Chinese plans related to trade. The route (or at present, routes) that the trade takes place on is prevalent over sea and only marginally presides over land. Most of the goods currently traded between China and Europe travel by cargo ships from East to West. If this trend inverts in the future, the Silk Road route that will emerge will have a decisive economic impact on the future of Central and Eastern Europe. At present, the Chinese initiative has greater importance in terms of geopolitical strategy than economic benefit. In comparison to maritime trade, the amount of goods going across Asia is minimal; the reason why the current initiative is important is because it can improve not just trade but connectivity between the two continents in general. It raises both political entities - China and Europe - simultaneously, offers more opportunities for cooperation and creates the foundation of common principles to ascertain a new world order. An international environment with not just Western, but Chinese characteristics, dominated by amity. These are the long-term goals of the OBOR. However, first and foremost, Chinese efforts lie in the development of its western neighbors; thereby, the routes and the shape of the European end of the Economic Belt will remain a secondary issue (Liu, 2014, p. 5).

Balázs Sárvári is a teacher assistant at Corvinus University of Budapest. His major fields of research are political economics of globalization and cultural heritage and China's position in global issues. 
Anna Szeidovitz is a student and research assistant at Corvinus University of Budapest. She is currently doing her master's degree in international business and economics, and holds a BA in international relations.

\section{Bibliography}

Andrea, A. J. (2014), The Silk Road in World History: A Review Essay. Retrieved from http://www.thearwh.org/journal/arwh_2-1_andrea.pdf [accessed Oct 2015]

Brugier, C. (2014), China's way: the new Silk Road, EUISS Brief no. 14, Paris: ISS. Retrieved from: http:/www.iss.europa.eu/publications/detail/article/chinas-waythe-new-silk-road [accessed Oct 2015]

China Institute in America (2015), Exchange of Goods and Ideas Along The Silk Roads. Retrieved from http://www.chinainstitute.cieducationportal.org/cimain/wpcontent/themes/chinainstitute/pdfs/education/fromsilktooil_pdf5.pdf [accessed Oct 2015]

Dawber, A. (2015), "China to Spain cargo train: Successful first 16,156-mile round trip on world's longest railway brings promise of increased trade," Independent, 24 February 2014. Retrieved from: http://www.independent.co.uk/news/world/ europe/china-to-spain-cargo-train-successful-first-16156-mile-round-trip-onworlds-longest-railway-brings-10067895.html [accessed Jul 2015]

EEAS (2013), EU-China 2020 Strategic Agenda for Cooperation, European Union External Action. Retrieved from http://eeas.europa.eu/china/docs/20131123 agenda_2020_en.pdf [accessed Oct 2015]

Erdősi, F. (2015), 'Trans-Eurasian transport links in great and medium-size spaces of power,' Tér és Társadalom, vol. 29, no. 2, pp. 106-126. http://dx.doi.org/10.17649/ TET.29.2.2677

Fedorenko, V. (2013), The New Silk Road Initiatives in Central Asia, Rethink Paper 10. Retrieved from http://www.rethinkinstitute.org/wp-content/uploads/2013/11/ Fedorenko-The-New-Silk-Road.pdf [accessed Oct 2015]

Felföldi, Sz. (2009), Egy új szemléletü Selyemúttörténet alapvonalaihoz. Retrieved from http://okorportal.hu/wp-content/uploads/2013/06/2009_2_felfoldi.pdf [accessed Oct 2015]

Freedholm, J. (2011), 'The Dynamics of Trade along the Silk Road,' SPICE Curriculum guide. Retrieved from http://www.globalcultures.net/shepard/worldblog/wpcontent/uploads/2011/01/Dynamics-of-Trade.pdf [accessed Oct 2015]

Fung Business Intelligence Centre (2015), The Silk Road Economic Belt and the 21st Century Maritime Silk Road. Retrieved from https://www.fbicgroup.com/sites/ default/files/The\%20Silk\%20Road\%20Economic\%20Belt\%20and\%2021st\%20 Century\%20Maritime\%20Silk\%20Road\%20MAY\%2015.pdf [accessed Oct 2015] 
Geeraerts, G. (2011), 'China, the EU, and the new multipolarity,' European Review, vol. 19, no. 1, pp. 57-67. http://dx.doi.org/10.1017/S1062798710000335

Godement, F. (2015), “'One belt, one road”: China's great leap outward, China Analysis, 10 June, London etc.: European Council on Foreign Relations.

Hansen, V. (2012), The Silk Road: A New History, Oxford: Oxford University Press.

Heilmann, S.; Rudolf, M.; Huotari, M. \& Buckow, J. (2014), “China's Shadow Foreign Policy: Parallel Structures Challenge the Established International Order,' Merics: China Monitor, no. 18, 28 October. Retrieved from: http://www.merics. org/fileadmin/templates/download/china-monitor/China_Monitor_No_18_en.pdf [accessed in October 2015]

Huang, Y. (2015), “Don't Let 'One Belt, One Road' Fall into the Trap of Japan's Overseas Investments," Zhongguo Gaige Wang, 10 February.

Inotai, A. (2010), 'Impact of the global crisis on trade relations between the European Union and China,' in Hungarian Statistical Review, vol. 14, pp. 46-67.

— (2011a), "Kína világgazdasági szerepének erősödése, az exportorientált 'modell' jövője,” Köz-gazdaság, vol. 6, no. 1, pp. 215-218.

(2011b), 'Impact of the global crises on EU-China relations: facts, chances and potential risks,' in T. Matura (ed.) Asian Studies, Budapest: Hungarian Institute of International Affairs, pp. 80-102.

(2014), 'Economic relations between the European Union and China,' L'Europe en Formation, vol. 2013/4, no. 370, pp. 47-84. http//dx.doi.org/10.3917/ eufor.370.0047

Jia, Q. (2015), 'A number of issues that the OBOR urgently needs to clarify and prove,' Aisixiang, 24 March.

Juhász, O. (2015), 'A Selyemúton oda-vissza,' Remény, 2. szám. Retrieved from http:// www.remeny.org/remeny/2015-2-szam/juhasz-otto-a-selyemuton-oda-vissza/ [accessed Dec 2015]

Jun, Z. (2015), 'China's pursuit of a new economic order,' Project Syndicate, 2 June. Retrieved from http://www.project-syndicate.org/commentary/china-new-worldorder-by-jun-zhang-2015-06 [accessed Oct 2015]

Kaczmarski, M. (2015), “The New Silk Road: a versatile instrument in China's policy," $O S W, 2$ October. Retrieved from http://www.osw.waw.pl/en/publikacje/ osw-commentary/2015-02-10/new-silk-road-a-versatile-instrument-chinas-policy [accessed Oct 2015]

Karluk, S. R. \& Karaman, S. C. (2014), 'Bridging civilizations from Asia to Europe: The Silk Road,' Chinese Business Review, vol. 13, no. 12, pp. 730-739. http// dx.doi.org/10.17265/1537-1506/2014.12.00.

KPMG (2015), China Outlook 2015, KPMG Global China Practice. Retrieved from http://www.kpmg.com/ES/es/Internacionalizacion-KPMG/Documents/ChinaOutlook-2015.pdf [accessed Oct 2015] 
Lai, S-Y. \& Zhang, L. (2013), “Challenging the EU's economic roles? The impact of the Eurozone crisis on EU images in China," Baltic Journal of European Studies, vol. 3, no. 3, pp. 13-36. http://dx.doi.org/10.2478/bjes-2013-0019

Lawton, J., ed. (2008), Integral Study of the Silk Roads: Roads of Dialogue, Paris: UNESCO. Retrieved from http://unesdoc.unesco.org/images/0015/001592/ 159291eo.pdf [accessed Oct 2015]

Laruelle, M. (2015), 'The Chinese Silk Road and their Reception in Central Asia,' Testimony before the U.S.-China Economic and Security Review Commission Hearing on 'Looking West: China and Central Asia.' Retrieved from http://www. uscc.gov/sites/default/files/Laruelle\%20Testimony_3.18.15.pdf [accessed Oct 2015]

Li, J. (2014), 'Report: Silk Road Economic Belt may be divided into three phases; initial completion predicted in 2049,' Zhongguo Xinwen Wang, 28 June.

Liu, X. (2010), The Silk Road in World History, Oxford: Oxford University Press.

Liu, Z. (2014), Central and Eastern Europe in Building the Silk Road Economic Belt, Working Paper Series on European Studies, Institute of European Studies, Chinese Academy of Social Sciences, vol. 8, no. 3.

Marshall, G. (1947), Speech given by United States Secretary of State, General George Marshall at Harvard University, 5 June.

Matura, T. (2012), 'The pattern of Chinese investments in Central Europe,' International Journal of Business Insights \& Transformation, Special Issue, vol. 5, no. 3, pp. 104-109.

Maxxelli Consulting (2015), West China's International Railway Development. Retrieved from http://www.maxxelli-consulting.com/west-chinas-internationalrailway-development/ [accessed Oct 2015]

Men, J. (2015), "China's New Silk Road and EU-China relations," in EU-China Observer, no. 1.15, pp. 12-15.

Messenger (2014), 'Reimagining the Silk Road,' vol. 25, no. 5. Retrieved from http:// issuu.com/nicktsui/docs/messenger_silkroad_for_issuu [accessed Oct 2015]

Ministry of Foreign Affairs of the People's Republic of China (2013), President Xi Jinping Delivers Important Speech and Proposes to Build a Silk Road Economic Belt with Central Asian Countries, 7 September. Retrieved from http://www. fmprc.gov.cn/mfa_eng/topics_665678/xjpfwzysiesgjtfhshzzfh_665686/t1076334. shtml [accessed Oct 2015]

van der Putten, F.-P. \& Meijnders, M. (2015), 'China, Europe and the Maritime Silk Road,' Clingendael Report, 26 March. Clingendael: Netherlands Institute of International Relations. Retrieved from http://www.clingendael.nl/sites/default/ files/China \%20Europe\%20and\%20the\%20Maritime\%20Silk\%20Road.pdf [accessed Oct 2015] 
Railway Road Connections Map (2005), 'Railway and Road Corridors Connecting the Central Asia Regional Economic Cooperation Member Countries,' [image] Central Asia Regional Economic Cooperation. Retrieved from http://www.carecprogram. org/uploads/events/2005/4th-MC/001_101_213_Railway-Road-ConnectionsMap.pdf [accessed Oct 2015]

Railway Gazette (2015), 'DB Schenker launches Hamburg-Zhengzhou train,' 5 September. Retrieved from http://www.railwaygazette.com/news/freight/singleview/view/db-schenker-launches-hamburg-zhengzhou-train.html [accessed Oct 2015]

Rolland, N. (2015), "China's New Silk Road," The National Bureau of Asian Research (NBR), 12 February.

Schweisgut, H. D. (2015), 'EU-China 40th Anniversary: Expectations for Expanding Connections, in EU-China Observer, no. 1.15, pp. 7-10.

Staburova, J. \& Bērziņa, U. A. (2013), 'Glimpse at EU-China relationships since 2008,' Baltic Journal of European Studies, vol. 3, no. 1, pp. 44-57. http://dx.doi.org//10.2478/bjes-2013-0004

Stahl, A. K. (2015), “China's New Silk Road Diplomacy: Implications for China's Relations with Europe and Africa," in EU-China Observer, no. 1.15, pp. 16-19.

Szczudlik-Tatar, J. (2013), China's New Silk Road Diplomacy, PISM Policy Paper, no. 34 (82). Retrieved from https://www.pism.pl/files/?id_plik=15818 [accessed Oct 2015]

Tao, X. (2014), "Back on the Silk Road: China's version of a rebalance to Asia,' Global Asia, vol. 9, no. 1. Retrieved from http://www.globalasia.org/wp-content/ uploads/2014/03/548.pdf [accessed Oct 2015]

The World Bank (2015), The World Bank Investor Brief. Retrieved from http://treasury. worldbank.org/cmd/pdf/WorldBankInvestorBrief.pdf [accessed Oct 2015]

TRACECA (2012), Silk Wind: The Route of Multimodal Block Train (Project Progress Presentation), National Secretariat of IGC TRACECA in the Republic of Kazakhstan. Retrieved from http://www.traceca-org.org/uploads/media/14 Presentation_Silk_Wind_07-11-12_eng.pdf [accessed Oct 2015]

Trautmann, L. \& Gervai, P. (1999), 'Ázsiai kultúra és információs társadalom,' Fordulat, 1999 ősz, pp. 53-76.

Turcsányi, R. (2014), 'Central and Eastern Europe's courtship with China: Trojan horse within the EU?' EIAS: EU-Asia at a Glance, January. Retrieved from: http://www. eias.org/sites/default/files/EU-Asia-at-a-glance-Richard-Turcsanyi-China-CEE. pdf [accessed Oct 2015]

Txabarriaga, R. (2010), 'Implications of increasing Europe's trade with China, Tcworld, February. Retrieved from http://www.tcworld.info/e-magazine/outsourcing/ article/implications-of-increasing-europes-trade-with-china/ [accessed Oct 2015] 
Vangeli, A. (2015), "China's New Silk Road and its impact on Sino-European relations," in EU-China Observer, vol. 1.15, pp. 20-26.

Värk, J. (2013), 'Russia between China and the European Union: Friends or Foes?' Baltic Journal of European Studies, vol. 3, no. 1(13), pp. 29-43. http://dx.doi.org/10.2478/bjes-2013-0003 (2015), "China's dilemmas on the road to reform under Xi Jinping," Baltic Journal on European Studies, vol. 5, no. 1, pp. 133-149. http://dx.doi.org/10.1515/bjes2015-0009

Wang, J. (2012), “'Marching towards the West', China's geopolitical strategy of rebalancing," Huanqiu Shibao, 17 October.

Waugh, D.C. (2010), 'The silk roads in history,' Expedition, Special Issue: Silk Road, vol. 52, no. 3, pp. 9-22. Retrieved from http://faculty.washington.edu/dwaugh/ publications/waughexpeditionfinal.pdf [accessed Oct 2015]

Wood, F. (2002), The Silk Road: Two Thousand Years in the Heart of Asia, Berkeley, Los Angeles: University of California Press.

Xu, G. (2014), "Looking at the 'One Belt, One Road' strategy from a return on investment point of view," Financial Times (Chinese version), 20 November.

Yanchun, W. (2015), "Reconstructing China's trade," Caijing, 2 February.

Yang, Y. (2015), 'China-EU Relations: Broader, Higher and Stronger,' in EU-China Observer, vol. 1.15, pp. 6-7.

Yiping, H. (2015), “Don't Let 'One Belt, One Road' Fall into the Trap of Japan's Overseas Investments," Zhongguo Gaige Wang, 10 February.

Zhang, J. (2015), “China's pursuit of a new economic order,' Project Syndicate, 2 June. Retrieved from http://www.project-syndicate.org/commentary/china-new-worldorder-by-jun-zhang-2015-06?barrier=true [accessed June 2015]

Zheng, X. (2014), “'One Belt, One Road' is not 'China's Marshall Plan'," Huanqiu Wang, 17 November.

Zheng, Y. (2015), “The 'One Belt, One Road' strategy helps the world economy rebalance," Lianhe Zaobao / Oriental Morning Post, 8 January. 